International Journal of Chemistry and Materials Research

2021 Vol. 9, No. 1, pp. 1-18.

$\operatorname{ISSN}(e): 2311-763 \mathrm{X}$

$\operatorname{ISSN}(p): 2312-0991$

DOI: 10.18488/journal.64.2021.91.1.18

(C) 2021 Conscientia Beam. All Rights Reserved.

check for
updates

\title{
GREEN CHEMISTRY AND PROCESS INTENSIFICATION: MILESTONES ON A SUSTAINABLE DEVELOPMENT
}

(iD) Djamel
Ghernaout $^{1+}$
(D) Noureddine
Elboughdiri $^{2}$
(D) Ramzi Lajimi

\author{
'Chemical Engineering Department, College of Engineering, University of \\ Ha'il, Ha'il, Saudi Arabia; Chemical Engineering Department, Faculty of \\ Engineering, University of Blida, Algeria. \\ Email:Djamel_andalus@hotmail.com \\ ${ }^{2}$ Chemical Engineering Department, College of Engineering, University of \\ Ha'il, Ha'il, Saudi Arabia; Chemical Engineering Process Department, \\ National School of Engineering, University of Gabes, Gabes, Tunisia. \\ Email: ghilaninouri@yahoo.fr \\ ${ }^{3}$ Department of Chemistry, College of Science, University of Ha'il, Ha'il, \\ Saudi Arabia; Laboratory of Water, Membranes and Environmental \\ Biotechnologies, Center of Researches and Water Technologies, Tunisia. \\ Email:r.lajimi@uoh.edu.sa
}

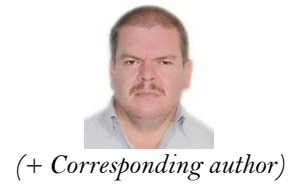

(+ Corresponding author)

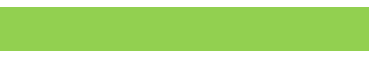

Article History

Received: 12 July 2021 Revised: 18 August 2021 Accepted: 6 September 2021 Published: 21 September 2021

\section{Keywords}

Green chemistry (GC)

Life-cycle assessment (LCA)

Process intensification (PI)

Heat and mass transfer (HMT)

Sustainable development

Chemical engineering.
As a philosophical support, green chemistry (GC) becomes at present well-combined into the scientific system to assist scientists and engineers consider how to decrease or remove waste and avert the employment and formation of hazardous substances in the design phase of chemicals. Such design attempts in turn affect the full life-cycle of the chemical, from getting the starting materials until the end-use product is recycled or disposed of. There is a considerable advance noted in such direction during the last three decades, this review focuses on GC research. As a comparatively fresh technique, revision in process intensification (PI) is fast and investigation could rapidly lead to outstanding outcomes. However, numerous features of PI could take more time to be fact. Much of the study stays in academic and industrial laboratories, even if large-scale implementations of micro-reactors are actuality. Fields of PI enterprise that have progressed quickly are the expansion of carbon capture techniques, an increasing interest in GC, and the beginning of momentous study into connecting solar energy to intensified methods like chemical reactions. Electric fields (e.g., microwaves and ultrasound) are observed in larger usages, and the application of electrokinetic forces at the micro- and nanoscale persist to fascinate. Huge investigations are working for the sake of ideas like the perfect reactor. PI remains a motif leading to attain a sustainable society. This work may be an orientation in the investigation of product development and design, production and application, in a constructive and stimulating way.

Contribution/Originality: This study documents green chemistry (GC) and process intensification (PI) as milestones on a sustainable development. GC becomes well-combined into the scientific system to assist engineers in decreasing waste and averting the formation of hazardous substances. PI investigation could lead to outstanding outcomes especially in product development and design.

\section{INTRODUCTION}

During the last quarter century, green chemistry $(\mathrm{GC})$ has furnished a background for chemical engineers to participate in the large field of global sustainability [1-3]. Thousands of researches and publications were dedicated to furnish a rich data to the chemical engineers and others for recognizing present troubles and proposing solutions 
[4-6]. The present work constitutes an appropriate domain to emphasize several of the most important axes on the wide topic of GC $[1,2]$.

There is an increasing interest towards GC [7, 8]. As an example, recently (June 14-June 18, 2021) a Green Chemistry \& Engineering Conference took place virtually on the theme "Sustainable Production to Advance the Circular Economy" [1, 2]. It called attention to the fact that contributions should consider a systems approach to decreasing ecological effect via intentional design of chemicals, not just considering how raw materials are sourced and in the fabrication and employment of industrial and consumer goods but also how such materials and goods could be reused, recycled, or upcycled [2, 9, 10]. Adopting life-cycle thinking as a target among the GC community emerges at the backdrop of the recognition of restricted resources and a climate crisis [11-13]. The following axes seem to be determining steps on the route to progress closed-loop economies while still working as models for innovation at a basic scale within their respective chemistry sub-disciplines [2, 14, 15$]$.

The motivation for efficacy in organic synthesis combines the best of the idealisms of the Enlightenment and the Renaissance [2]. Surely, there is a premium on rationalism, with an aspiration of mechanistically sound reaction design and process development [16-18]. However, simultaneously, the aesthetic appeal of the fresh thoughts that peak in the progresses we presently touch usually is evident [19-21]. There is no limitation on curiosity when we examine the boundary conditions of efficacious, environmentally benign techniques [22-24]. Conversely, such reflections generated novel concepts and approaches, ranging from postmodern expansions of photochemistry [12, $25,26]$ reconsideration of seminal thinking about solvation, importation of physical and mechanical phenomena [27-29] to reaction development - the creativity born of efficiency considerations now drives major technology innovation in chemistry [2, 30,31].

\section{REDUCING DEPENDENCE ON FOSSIL FUELS}

Designing techniques for circularity requires multidisciplinary methods and accurate description of the trouble being handled [32]. One of the pivotal dares encountered remains to be diminishing humankind dependence on fossil fuels for chemical and fuel production [2]. This necessitates both the efficacious and clean transformation of renewable (biobased) raw materials into functional chemicals and fuels, as well as efficacious $\mathrm{CO}_{2}$ capture and conversion into fuels and chemicals Ganesh, et al. [2]. Wang, et al. [33] examined the expansion and usage of engineered multifunctional nanohybrids of carbon nanomaterials and metal/metal oxide nanoparticles, which exhibit promising multifunctionalities for addressing the critical energy-water-environment nexus [2].

More precisely in terms of $\mathrm{CO}_{2}$ capture and use, Halliday and Hatton [34] defined a pivotal dare for carbon capture and storage (CCS) - the quest for net-negative emissions. They noted that bioenergy with carbon capture and storage (BECCS) with molten sorbents present a distinctive chance to obtain net-negative emissions with minimal indirect emissions and low-cost separation of $\mathrm{CO}_{2}$ from other gases [2]. BECCS can eliminate $300-850 \mathrm{~kg}$ of $\mathrm{CO}_{2}$ equivalents from the atmosphere per megawatt-hour of electrical output $(\mathrm{kg} / \mathrm{MWh})$, rendering it superior to other low carbon techniques and allowing the offset of emissions from hard-to-abate industries. Focusing on efficacious materials for carbon capture, Jiang, et al. [35] noticed the expansion of light-responsive metal-organic frameworks (LMOFs) that possess tunable structures and performances. Whilst traditional amines could not attain controllable adsorption separation, such LMOFs possess tunable amine-based active sites that ameliorate $\mathrm{CO}_{2}$ capture and control adsorption and separation. Some progresses as well call attention to the enhancement of techniques for decrease of $\mathrm{CO}_{2}$ founded on electrocatalytic techniques, comprising the employment of $\mathrm{Ru}$ and $\mathrm{Re}$ catalysts [36] and the usage of ionic liquids for such implementation [37] as well as investigation of Earthabundant iron catalysts [38]. Complementary to electrochemical processes, enzymatic [39] and photocatalytic [35] techniques are as well proved to possess a position in the toolbox for conversion and usage of $\mathrm{CO}_{2}[2]$.

The efficacious and clean transformation of renewable raw materials into functional chemicals and fuels has emerged from a theoretical construct to an interdisciplinary field that is fueled by fundamental innovations in 
synthetic chemistry and guided by practical applications of biorefineries [2]. The needs of biorefineries for flexibility of feedstocks, comparatively mild running circumstances, and low ecological effect have conducted to highly innovative techniques for defunctionalizing and refunctionalizing biomass feedstocks to value-added chemicals and materials. Relating to the defunctionalization front, Yang, et al. [40] observed an organocatalytic technique for photochemical $\mathrm{C}-\mathrm{O}$ bond cleavage of the $\beta-\mathrm{O}-4$ linkage in lignin scaffolds. Such process furnishes a metal-free strategy to prior reports and is applicable to continuous flow processing. Cellulose-derived platform chemicals could as well be obtained more efficiently from using a redox-switchable biocatalyst for controllable oxidation or reduction of 5-hydroxymethylfurfural into high-value derivatives [41].

Extending the range of new platform chemicals that could be obtained from biomass, Del Río, et al. [42] defined the occurrence of valuable phenolic compounds embodied into lignins (like flavonoids, hydroxystilbenes, and hydroxycinnamic amides) that conduct as authentic lignin monomers and are considerably obtainable in big quantities from the abundant in waste products from processing of agricultural or forest biomass. Nakagawa, et al. [43] explored the utility of erythritol as a $\mathrm{C} 4$ platform in biomass refinery, derived from fermentation of sugars and glycerol [2].

The direct valorization of lignin to functional chemicals constitutes possible novel approaches for efficaciously transforming lignin to chemicals Ganesh, et al. [2]. Dong, et al. [44] noticed a lignin-carbohydrate complex that is an effective antioxidant for scavenging reactive oxygen species in vitro and zebrafish in vivo. Further, lignin was employed in the fabrication of polyurethane generated by oxidative liquefaction [45]. Several different conversions of biomass to functional chemicals and materials are examined in two deep discussions on biomass-derived carbonaceous materials [46] and bacterial cellulose-based composite scaffolds for biomedical applications [47]. Relating to transforming our polymer platform to renewable materials, consistent with the circular economy, Zhao, et al. [48] examined how we could close the gap for bioplastic usage in single-use food packaging, focusing on the most recent development successes in bioplastic materials and highlighting the "gaps" between bioplastics and their conventional counterparts with respect to their properties [2, 49].

\section{REDUCING THE EFFECT OF CHEMICAL SYNTHESIS AND MANUFACTURING}

For a circular economy, in promoting industrialization infrastructure, one more pivotal dare stays the reduction of the overall environmental footprint [2]. Such reduction must decrease both the environmental effect of the industrialization techniques of chemicals as well as their likely risks and persistence of the commodity chemicals produced [50-52]. While the former has been a cornerstone of research in GC from its inception in the early $1990 \mathrm{~s}$, it is still a fertile area of research [53-55]. The latter will be addressed in further detail later in this work.

In organic chemistry (particularly in organic synthesis), sustainability continues to a driving innovation for many years [2]. With the quantity of waste formed in numerous synthetic chemistry approaches, we are faced with not only an ethical imperative to promote more sustainable chemical methods and products but also a financial imperative [56-58]. Metrics to gauge such advance, comprising process mass intensity, have been suggested that let all aspects of a technique to be contrasted. As an illustration, controlling a reaction in water may not necessarily be an amelioration if several volumes of an organic solvent are required to extract/purify the product. A fresh perspective calls attention to the necessity to explicitly comprise the evaluation of sustainability employing GC metrics [59].

Several researchers focused on progresses in catalysis and reaction engineering that conducted to waste and energy reduction for techniques that remain constitute important dares [2]. Some scientists concentrated on usage of less toxic reagents, catalysts, or routes [60-62]. In terms of catalysis front, there is an augmentation in the field of synthetic transformations assisted by supported catalysts [63, 64]. As an illustration, Wang, et al. [65] defined the fabrication of a reusable magnetic $\mathrm{Ag}-\mathrm{Fe}_{3} \mathrm{O}_{4}$ catalyst supported on cellulose microspheres for reduction of nitrophenols. Further, there is an augmentation in examination of the usefulness of base metals in catalysis and 
organocatalytic methods being realized under mild conditions and with low catalyst loading. Indeed, for highly enantioselective epoxidation of $\alpha, \beta$-unsaturated ketones, Majdecki, et al. [61] used an amide-based Cinchona alkaloid at loadings as low as $0.5 \mathrm{~mol} \%$ as a hybrid phase-transfer organocatalyst.

In terms of application, the demand for minimizing typically elevated $E$-factors in the pharmaceutical sector persists Ganesh, et al. [2]. Andrews, et al. [66] and Isidro-Llobet, et al. [67] focused on the necessity to suggest less uneconomical and poisonous techniques for peptide and oligonucleotide synthesis and purification approaches, in light of the growing utility of biological peptide-based pharmaceuticals. Rossen [68] underlined insights from process chemistry that could diminish the effect of synthetic chemistry at smaller scales, and Hayler, et al. [69] presented a perspective from the pharmaceutical industry on the role of catalysis with Earth-abundant metals.

Catalysis using Earth-abundant rather than costly metals persists to be an active domain of experimentation and crucial component of sustainable chemistry testing [2]. Researchers worked on cobalt [70] and iron [71] catalysts for hydrosilylation and nickel precursors and heterogeneous catalysts for Suzuki-Miyaura coupling, one of the most largely employed processes for $\mathrm{C}-\mathrm{C}$ bond generation. Further, Van Putten, et al. [72] observed the role of manganese in mediating $\mathrm{C}-\mathrm{C}$ bond generation from organoboranes.

Further, waste lowering persists to be tackled in terms of solvent in suggesting alternative solvents, like less poisonous task-specific ionic liquids, deep eutectic solvents, and augmenting the field and efficacy of reactions in water (e.g., amidation, amine synthesis, and transfer hydrogenation [2]. There is as well the expansion of novel biomass-derived solvents with greener profiles like glycerol-derived 1,2,3-triethoxypropane and systematic solvent selection protocols for "greener" solvents [2].

\section{DESIGNING CHEMICAL PRODUCTS WITH LOWER DANGER}

Whilst reducing the influence of chemical agents out of usage of renewable resources and cleaner techniques stays crucial, the significance of the toxicological profile of the chemical products being circulated becomes yet more and more being realized $[2,73,74]$. The dare of efficaciously estimating the toxicological hazards of thousands of chemical products at the design step and for chemical agents already in usage needs interdisciplinary research efforts [75-77]. Several toxicological pathways of interaction stay defectively comprehended and thus unregulated Ghernaout and Elboughdiri [78]; Saiba, et al. [79]; Boucherit, et al. [80]. Chen, et al. [81] defined how in silico techniques of molecular dynamic simulations will assist to describe molecular initiation events and identify toxicological pathways, authorizing rapid and efficient screening of a broader collection of chemical products. Moreover, Kwiatkowski, et al. [82] suggested that individual testing of thousands of chemical products is impractical, and chemical "classes" have to be screened employing large subclasses as needed. Blum, et al. [83] furnished outstanding illustrations of the regrettable substitution of polybrominated diphenyl ethers with organophosphate ester flame retardants, conducting to unwanted toxicological consequences, and Kwiatkowski, et al. [82] adopted the scientific bases for dealing with perfluoroalkyl chemicals as a class.

The design of plastics to be both biodegradable and sustainably generated from non-petrochemical sources is one more crucial circular design domain requesting pressing research input Ganesh, et al. [2]. Napper and Thompson [84] announced a shortage of biodegradable plastic formulations utilized for carrier bags that displayed rapid rates of degradation juxtaposed to traditional plastic bags. Relating to ecological worries, Grbic, et al. [85] suggested a new and easy procedure to evaluate the amounts of microplastic fragments in environmental matrices, employing hydrophobic [86] iron nanoparticles to extract microplastics from soil, sediments, and water magnetically $[19,21]$ and can be utilized as a sustainable remediation tool.

\section{SUSTAINABLE WATER RESOURCES}

The sustainable supply of drinking water remains a universal obligation Ganesh, et al. [2]; Ghernaout [87]; Ghernaout [88]. Ghimire, et al. [89] presented a crucial estimation and perspective of two main pathways for 
promoting more sustainable and circular-economy-founded wastewater treatment and depicted that combining both concepts may lead to superior energy and resource efficiency for wastewater treatment systems Ghernaout, et al. [90]; Ghernaout and Elboughdiri [91]; Ghernaout and Elboughdiri [92]. Eggensperger, et al. [93] mentioned the usage of self-healing bacterially generated cellulose fiber networks producing sustainable biological membranes apt to filter water for potable water purposes. Bentel, et al. [94] announced that alternative energy-efficient and sustainable remediation methods comprising the implementation of ultraviolet (UV)/sulfite water treatments could furnish efficient decay of persistent with perfluoroalkyl chemicals in raw water for onward potable water use.

Further, environmentally sustainable and energy-efficient nanotechnology membranes possess water purification usages [95-97] frequently in integration with additional environmental usages, comprising energy harvesting, environmental sensing, and remediation [2, 98, 99]. Desalination techniques with superior high efficiency are founded on selective desalination membranes [11,31,100] and reduced graphene oxide membranes with minimal impact of nanowrinkles [101]. In addition to desalination, the decomposition of persistent organic pollutants stays as well a fundamental concern for water treatment. Pan, et al. [102] worked on the usage of a porous, coral-like nanostructure photoelectrode for such objective whilst jointly generating electricity. Shao, et al. [103] defined routes of carbo-catalysis in carbon nanotubes with persulfate oxidation for water treatment implementations.

\section{CLOSING THE LOOP}

The environmentally sustainable recuperation of resources from wastes is as well a flourishing domain of study Ganesh, et al. [2]. Chamas, et al. [104] described benchmarks for decay rates of usual plastics that will assist in prioritizing future study attempts on chemical decay to close the loop. Parker, et al. [105] investigated the depolymerization of ethylene with palladium catalysts to comprehend techniques to remediation of polyolefins. Liu, et al. [106] focused on the recuperation of lithium from spent batteries employing an acid-free mechanochemical method, which uses salt and sodium carbonate as the sole reagents. Wu, et al. [107] discussed the usage of selective sorbents for the elimination and recuperation of phosphates from wastewaters. Researchers [108] depicted the recuperation of nitrogen from sewage sludge and livestock manure as offering some circularity to the high global demand for nitrogenous fertilizers. Jun, et al. [39] suggested the capture and transformation of carbon dioxide to bicarbonate employing an environmentally easy setup of stabilized carbonic anhydrases loaded onto electrospun polymer nanofibers.

\section{LIFE-CYCLE AND SYSTEMS THINKING}

The possibility to implement life-cycle thinking to prioritize research and develop truly long-term, sustainable solutions remains crucial for defining potential routes to deal with circularity [2]. There are two frequent life-cycle assessment (LCA) methods (i.e., process LCA and economic input-output LCA), both of them are subjected to various limitations. Therefore, numerous combined methods are utilized to ameliorate the total accuracy. Luo and Ierapetritou [109] examined numerous integrated LCA methods over a case study of two biomass-based p-xylene fabrication techniques and suggested essential insights appropriate to future LCA. Moreover, LCAs of the production of broadly employed titanium dioxide nanoparticles [110] and butyl acetate [111] furnished conceptual directing for more sustainable synthesis of both. This procedure was used in suggesting the conversion of agricultural land in groundwater-stressed areas from irrigated crop types to rain-fed crop types combined with diversification to solar harvesting, so-called "agrivoltaics" [112].

In this work, the cited references typify the varied and interdisciplinary contributions relating to the topic discussed here [2]. They as well permit us to define fields that will demand more priority to greatly progress the domain toward implementations that smooth circularity [2]. Numerous of such fields are listed in Table 1. 
Table-1. Future research needs in developing a circular economy [2].

\begin{tabular}{l|l}
\hline Field & Description \\
\hline Field \#1 & $\begin{array}{l}\text { Depolymerization and defunctionalization processes for present chemical products that } \\
\text { could permit circularity, particularly for plastics. }\end{array}$ \\
\hline Field \#2 & $\begin{array}{l}\text { Design of circular systems taking into account human health and ecotoxicity, ideally } \\
\text { through rational design of benign commodity chemicals. }\end{array}$ \\
\hline Field \#3 & $\begin{array}{l}\text { Systematic implementation of LCA, or thinking, and process metrics in promoting fresh } \\
\text { manufacturing/synthetic procedures. }\end{array}$ \\
\hline Field \#4 & $\begin{array}{l}\text { Usage of machine learning and other big-data techniques [113-115] to direct innovation } \\
\text { toward novel paradigms of circularity. }\end{array}$ \\
\hline
\end{tabular}

\section{PROCESS INTENSIFICATION (PI)}

\subsection{Definition}

In the chemical engineering field, process intensification (PI) is described mostly in two principal manners: (1) PI greatly ameliorates transport rates, (2) it furnishes every molecule the identical processing chance [116, 117]. Such description could be viewed as being a process development implying greatly smaller tools that conducts to: (i) enhanced dominance of reaction kinetics furnishing bigger selectivity/reduced waste products; (ii) bigger energy efficiency; (iii) decreased capital costs; (iv) decreased inventory/improved intrinsic safety/fast response times [116].

In the heat transfer engineering, 'intensification' is similar to 'enhancement', and intensification is founded largely on active enhancement procedures, which are employed broadly in heat and mass transfer (HMT). Implementing PI successfully depends on the numerous techniques that may be employed to intensify unit operations and as well of many effective implementations [116].

The most frequently identifiable characteristic of an intensified process is that it is smaller, sometimes by orders of magnitude (ideally between 100- and 1000-fold [117]), than that it supersedes [116]. The structure distinctive to intensified processes (e.g., the pocket-sized' nitric acid plant) runs to offer the decrease in scale possible, employing very great HMT enhancement. From such compactness of factory, cleanliness and energyefficiency have tendency to be perceptible, especially in chemical processes and unit operations, at the same level with safety that is authorized by the implicit smaller inventories of what may be toxic chemical products that are passing through the intensified unit operations [116].

Throughout the 1970s, PI primarily caught remarkable interest in the chemicals domain, where it is most broadly known until now. Several PI techniques had been expanded before the phrase itself even occurred. As an illustration, any continuous process constitutes an intensification juxtaposed to the batch process [117] and the Podbielniak centrifugal contactor was suggested in the 1930s [116]. On the other hand, the benefits of PI are not usable only to the chemical industry but also in most process industries such as the food and pharmaceutical industries [116].

\subsection{Applying Process Intensification (PI) For Environment}

PI techniques possess very interesting ecological applications [117-119]. Indeed, a small, compact, greatly intensified factory is more possibly to be below the tree line, making it far less of an eyesore for the general public than the unsightly and massive steel works characterizing our current chemical factories [120-122]. Moreover, new reactor designs founded on the PI principle will authorize clean technique to be employed via letting waste reduction at origin [123-125]. In other words, high-selectivity operation in intensified reactors will diminish or banish completely the generation of undesirable by-products that if not eliminated from the effluent before discharge could provoke irreparable harm to the nature [126-128]. Thus, high-purity product will be acquired without enduring huge downstream purification prices [117, 129, 130].

The enhanced energy efficacy expected in intensified unit operations forms even an additional greatly interesting advantage of PI $[117,131,132]$. Indeed, PI is a favorable point for the chemical engineering [133-135] 
. As mentioned above, considerable ameliorations in HMT could be reached in intensified units [136-138]. These ameliorations imply that process periods and so energy consumption could be greatly decreased for a given operation [139-141]. In addition, alternative energy sources (e.g., microwave and light energy [17]) that can be selected to wanted process chemistries, may conduct to less energy waste than is frequently faced with traditional thermal energy sources Ghernaout, et al. [142]; Ghernaout, et al. [143]; Ghernaout and Elboughdiri [144]. Boodhoo and Harvey [117] presented a case study focusing on the energy-saving capacity of a PI technique.

\subsection{Dares of Applying Process Intensification (PI)}

As a consistent philosophy, PI was primarily suggested since the 1970s; this is why it has not had more influence until these days [117]. For the shortage of large application at the industrial level, there are many causes. Table 2 lists most of them.

Table-2. Reasons for the lack of broad usage of process intensification (PI) [117].

\begin{tabular}{l|l}
\hline Reason & Description \\
\hline Reason \#1 & $\begin{array}{l}\text { Reasonably, most of chemical plants are risk-averse. Further, for fresh techniques the danger } \\
\text { remains hard to evaluate. In fact, there is a shortage of both information and former case studies } \\
\text { on which to found designs and running, and so economic computations. The shortage of danger } \\
\text { and price details makes it hard to estimate the risk-reward balance and do a reliable cost- } \\
\text { benefit analysis for the process change. }\end{array}$ \\
\hline $\begin{array}{l}\text { Reason \#2 } \\
\text { Shortage of 'champions' } \\
\text { within industry }\end{array}$ & $\begin{array}{l}\text { At the organizational level, to perform any change there is a related individual with } \\
\text { responsibility for it. If such change is crucial and technological (e.g., the change to a new unit } \\
\text { operation in a chemical factory), the 'champion' will be forced to beat a lot of inertia, and should } \\
\text { be devoted and well-informed. Further, he must perfectly grasp the technique and its merits. }\end{array}$ \\
\hline $\begin{array}{l}\text { Reason \#3 } \\
\text { Control/ Monitoring }\end{array}$ & $\begin{array}{l}\text { The significantly improved rate of many intensified processes conducts to issues in monitoring, } \\
\text { since the response periods of the instruments begin to be important relatively to the process } \\
\text { period. This could be a significant added technical development step, and as such a barrier to } \\
\text { commercialization. To deal with such problems, several studies have been dedicated to } \\
\text { controlling more established PI technologies (e.g., reactive distillation and dividing wall } \\
\text { columns) [145, 146]. }\end{array}$ \\
\hline $\begin{array}{l}\text { Reason \#4 } \\
\text { PI's restrictions } \\
\text { seriesionally, PI could not be the solution. Indeed, any technique possesses a particular issue or } \\
\text { performing so is that feasibility studies (or pilot-scale tests) are realized that fail because the } \\
\text { premise was wrong (it was the inexact technique from the beginning), rather than due to any } \\
\text { technical failing, and the technology itself is then labelled as inadequate. Several techniques } \\
\text { presented have been classified as 'solutions seeking problems', and these problems will } \\
\text { sometimes be found. However, sometimes the question that is asked is, 'can this technology be } \\
\text { used for this application?', when it should be, 'does this technology have realizable economic } \\
\text { benefits for the process overall?' }\end{array}$ \\
\hline
\end{tabular}

Numerous of such dares are well known to anyone who has had a fresh technique to develop. The fresh technique should possess an established and considerable economic merit. Such economic merit is not only reached via diminishing the size of a piece of process equipment (or, preferably, the entire plant), but can be realized through some additional routes as listed in Table 3.

Table-3. Routes for bringing economic advantage besides reducing the size of the plant via applying process intensification (PI) [117].

\begin{tabular}{l|l}
\hline Route & $\begin{array}{l}\text { Accidents generate a price. Some function of the danger and consequent price of an accident must be } \\
\text { comprised into the economic estimation of any project. As a rule, intensified techniques will greatly } \\
\text { diminish the risk, and so price of any incident. More efficient monitoring that is more possibly with smaller } \\
\text { intensified equipment must assist in decreasing reduce the rate of incidence of accidents. }\end{array}$ \\
\hline $\begin{array}{l}\text { Safer } \\
\text { operation }\end{array}$ & $\begin{array}{l}\text { Enhanced product quality decreases the charge on downstream separations, possibly permitting a decrease } \\
\text { in size, or mohair techniques to be employed, or process stages to be avoided completely, that way } \\
\text { diminishing capital and running prices in other areas of the plant Figure } 1 \text { [147]. The higher product } \\
\text { quality generated in intensified methods thanks to the improved effectiveness of HMT diminishes the } \\
\text { quantity of waste formed, herewith reducing the quantity that must be disposed of. In many cases, where } \\
\text { the wastes are greatly poisonous, for example, treatment is one of the biggest running prices. }\end{array}$ \\
\hline $\begin{array}{l}\text { Product } \\
\text { quality }\end{array}$ & $\begin{array}{l}\text { She utmost performance of intensified factories diminishes energy prices. In a fossil fuel-founded energy } \\
\text { supply system, as most currently are, this equates directly to decreased CO emissions. These problems } \\
\text { must be more and more serious since carbon trading becomes more standard. }\end{array}$ \\
\hline
\end{tabular}




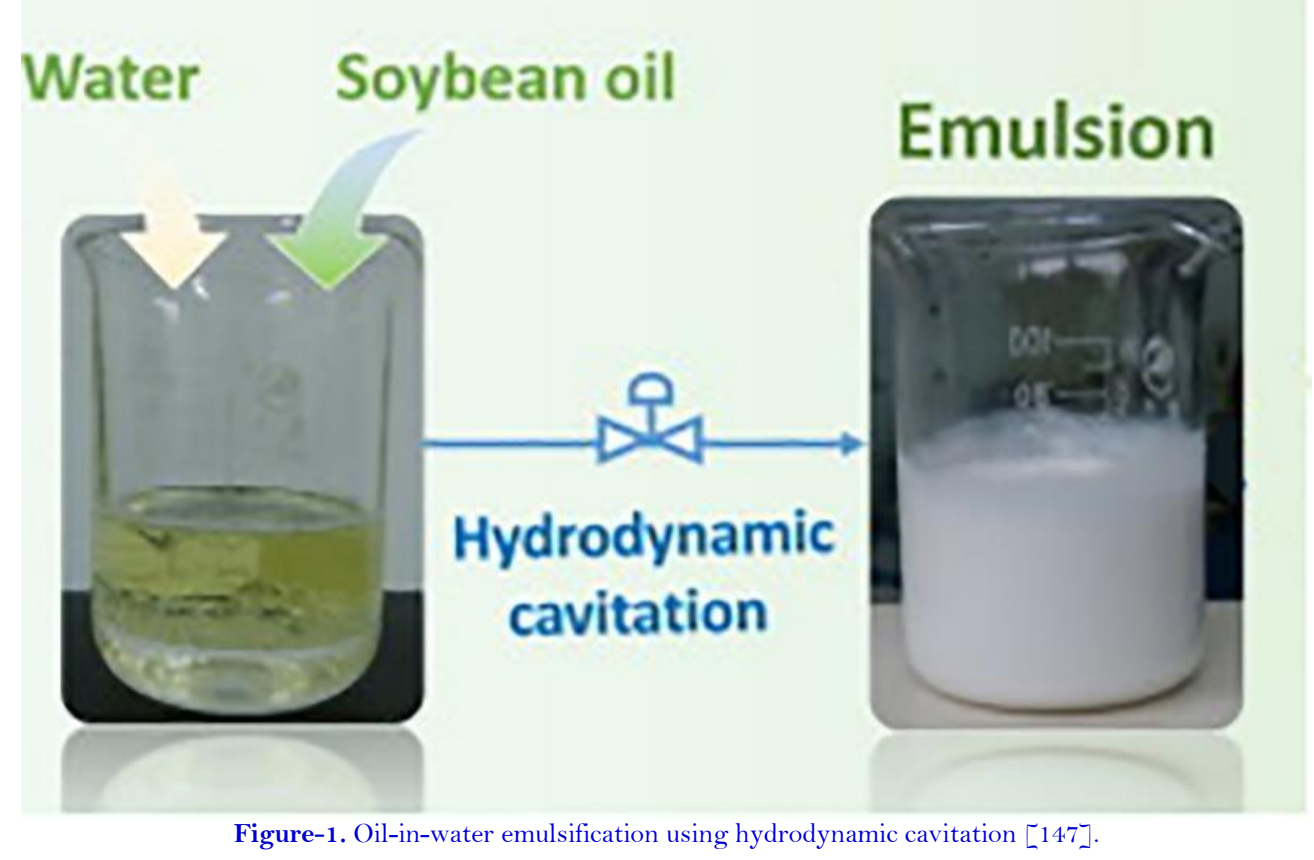

\section{CONCLUSION}

To permit future contributions to underline the feasible implementation to circular economies, numerous interrogations could be viewed. First, think about the source of the materials being utilized, and if it is fossil-fuelderived, see if there is a bio-founded alternative that may furnish the identical chemical insights. If elements are utilized that are encountering restricted supply, examine whether the synthetic techniques may aid in diminishing the usage of such materials. Second, consider whether the procedure defined may touch various steps of a chemical product's life-cycle. As an illustration, is it a sage that is possibly reversible founded on kinetics and thermodynamics? If it forms by-products, could those be a worthy resource? And finally, think about whether the process or product forms a safe product that could be either recycled, reused, or remanufactured. Dealing with such interrogations suggests the engineers to use life-cycle thinking and to enlarge their attention to the prior art most closely related to the progresses depicted. Next fruitful contributions to such domain from the innovative specialists are more than wanted [2].

2. During the previous three decades, PI has attained noteworthy activity as a radical program to chemical processing. As a result, considerable advances have been noticed in the research and development of PI techniques. With major stress being put on sustainable development, PI could be a crucial component in making future chemical and pharmaceutical industries greener. This is because it could be employed to importantly decrease the size of numerous unit operations, and in doing so diminish not only the energy needed to run them but as well the surrounding infrastructure and the energy and materials utilized in their fabrication. Bigger selectivity and yields may lead to ameliorated atom efficiency and waste minimization at source, conducting to the decrease of downstream processing. Certainly, PI will remain and persist to participate in the expansion of the chemical and processing industry. However, some dares stay needing a planned labor from both engineers and industry partners before PI is more largely applied. How effective PI is in its implementation to a selected process depends greatly on the features of that process. An inherently slow process will not be made any faster via intensifying HMT properties. Therefore, it remains substantial to visibly sense the basis of a process prior any trial at intensifying it is performed. On the other hand, there are more process-related restrictions to the universal usage of PI like: (i) many processes run at too small a scale for PI to be economically worthwhile, (ii) several factories need a flexibility of operation that is not easy to attain in a continuous factory, which is usually purpose-designed. Regardless of such implementation restrictions and dares, the potency for PI stays considerably not yet exploited. The economic 
recompenses for those plants that do introduce PI are likely to be substantial, and this will have ecological merits for a more sustainable future [117].

Funding: The Research Deanship of University of Ha'il, Saudi Arabia, has funded this research through the Project RG-20 113.

Competing Interests: The authors declare that they have no competing interests.

Acknowledgement: All authors contributed equally to the conception and design of the study.

\section{REFERENCES}

[1] ACS, "Green chemistry: A framework for a sustainable future. Retrieved from https://pubs.acs.org/page/vi/greenchemistry-

2021?utm_source=pubs_content_marketing\&utm_medium=email\&utm_campaign=PUBS_0621_KLR_AO_acsodf_Gr een_Chemistry_Joint_VI\&src=PUBS_0621_KLR_AO_acsodf_Green_Chemistry_Joint_VI\&ref=pubs_content_market ing_email_PUBS_0621_KLR_AO_acsodf_Green_Chemistry_Joint_VI\&\#.[Accessed 19/06/21]," 2021.

[q] K. N. Ganesh, D. Zhang, S. J. Miller, K. Rossen, P. J. Chirik, M. C. Kozlowski, J. B. Zimmerman, B. W. Brooks, P. E. Savage, D. T. Allen, and A. M. Voutchkova-Kostal, "Green Chemistry: A framework for a sustainable future," ACS Omega, vol. 6, pp. 16254-16258, 2021 .Available at: https://doi.org/10.1021/acsomega.1c03011.

[3] D. Ghernaout, B. Ghernaout, and M. W. Naceur, "Embodying the chemical water treatment in the green chemistryA review," Desalination, vol. 271, pp. 1-10, 2011 .Available at: https://doi.org/10.1016/j.desal.2011.01.032.

[4] D. Ghernaout, "The best available technology of water/wastewater treatment and seawater desalination: Simulation of the open sky seawater distillation," Chemistry, vol. 3, pp. 68-88, 2013.Available at: https://doi.org/10.4236/gsc.2013.32012.

[5] D. Ghernaout, "Disinfection and DBPs removal in drinking water treatment: A perspective for a green technology," International Journal of Advances in Applied Sciences, vol. 5, pp. 108-1 17, 2018.

[6] D. Ghernaout, "Environmental principles in the Holy Koran and the sayings of the Prophet Muhammad," American Journal of Environmental Protection, vol. 6, pp. 75-79, 2017.Available at: https://doi.org/10.1 1648/j.ajep.20170603.13.

[7] D. Ghernaout and N. Elboughdiri, "Water disinfection: Ferrate(VI) as the greenest chemical - A review," Applied Engineering, vol. 3, pp. 171-180, 2019.

[8] D. Ghernaout, "Electrocoagulation process: Achievements and green perspectives," Colloid and Surface Science, vol. 3, pp. 1-5, 2018.Available at: https://doi.org/10.11648/j.css.20180301.11.

[9] D. Ghernaout, "Short communication greening electrocoagulation process for disinfecting water," Applied Engineering, vol. 3, pp. 27-31, 2019.

[10] D. Ghernaout, "Greening cold fusion as an energy source for water treatment distillation - A perspective," American Journal of Quantum Chemistry and Molecular Spectroscopy, vol. 3, pp. 1-5, 2019.

[11] S. Irki, N. Kasbadji-Merzouk, S. Hanini, and D. Ghernaout, "Modelling of the coupling of desalination plants with the thermal solar energy system," Water Supply, vol. 20, pp. 1807-1822, 2020.Available at: https://doi.org/10.2166/ws.2020.092.

[12] K. Shahzad, M. I. Khan, N. Elboughdiri, D. Ghernaout, and A. U. Rehman, "Energizing periodic mesoporous organosilica (PMOS) with Bismuth and Cerium for photo-degrading methylene blue and methyl orange in water," Water Environment Research, vol. 93, pp. 1116-1125, 2021.Available at: https://doi.org/10.1002/wer.1519.

[13] D. Ghernaout, A. Alghamdi, M. Touahmia, M. Aichouni, and N. Ait Messaoudene, "Nanotechnology phenomena in the light of the solar energy," Journal of Energy, Environmental \& Chemical Engineering, vol. 3, pp. 1-8, 2018.Available at: https://doi.org/10.11648/j.jeece.20180301.11.

[14] D. Ghernaout, Y. Alshammari, and A. Alghamdi, "Improving energetically operational procedures in wastewater treatment plants," International Journal of Advanced and Applied Sciences, vol. 5, pp. 64-72, 2018.Available at: https://doi.org/10.21833/ijaas.2018.09.010. 
[15] D. Ghernaout and B. Ghernaout, "On the concept of the future drinking water treatment plant: algae harvesting from the algal biomass for biodiesel production-a review," Desalination and Water Treatment, vol. 49, pp. 1-18, 2012.Available at: https://doi.org/10.1080/19443994.2012.708191.

[16] D. Ghernaout, "The Holy Koran revelation: Iron is a "sent down" metal," American Journal of Environmental Protection, vol. 6, pp. 101-104, 2017.Available at: https://doi.org/10.11648/j.ajep.20170604.14.

[17] D. Ghernaout, "Water treatment chlorination: An updated mechanistic insight review," Chemistry Research Journal, vol. 2, pp. 125-138, 2017.

[18] D. Ghernaout, "Reverse osmosis process membranes modeling - A historical overview," Journal of Civil, Construction and Environmental Engineering, vol. 2, pp. 112-122, 2017.

[19] D. Ghernaout, "Magnetic field generation in the water treatment perspectives: An overview," International Journal of Advances in Applied Sciences, vol. 5, pp. 193-203, 2018.Available at: https://doi.org/10.21833/ijaas.2018.01.025.

[20] S. Irki, D. Ghernaout, M. W. Naceur, A. Alghamdi, and M. Aichouni, "Decolorization of methyl orange (MO) by electrocoagulation (EC) using iron electrodes under a magnetic field (MF). II. Effect of connection mode," World Journal of Applied Chemistry, vol. 3, pp. 56-64, 2018.Available at: https://doi.org/10.11648/j.wjac.20180302.13.

[21] D. Ghernaout and N. Elboughdiri, "Magnetic field application: An underappreciated outstanding technology," Open Access Library Journal, vol. 7, p. e6000, 2020.Available at: https://doi.org/10.4236/oalib.1106000.

[22] D. Ghernaout, B. Ghernaout, A. Saiba, A. Boucherit, and A. Kellil, "Removal of humic acids by continuous electromagnetic treatment followed by electrocoagulation in batch using aluminium electrodes," Desalination, vol. 239, pp. 295-308, 2009.Available at: https://doi.org/10.1016/j.desal.2008.04.001.

[23] D. Ghernaout, A. Mariche, B. Ghernaout, and A. Kellil, "Electromagnetic treatment-doubled electrocoagulation of humic acid in continuous mode using response surface method for its optimisation and application on two surface waters," Desalination and Water Treatment, vol. 22, pp. 311-329, 2010.Available at: https://doi.org/10.5004/dwt.2010.1120.

[24] S. Irki, D. Ghernaout, and M. W. Naceur, "Decolourization of methyl orange (MO) by electrocoagulation (EC) using iron electrodes under a magnetic field (MF)," Desalination and Water Treatment, vol. 79, pp. 368-377, 2017.Available at: https://doi.org/10.5004/dwt.2017.20797.

[25] D. Ghernaout and N. Elboughdiri, "UV-C/H2O2 and sunlight/ $\mathrm{H}_{2} \mathrm{O} 2$ in the core of the best available technologies for dealing with present dares in domestic wastewater reuse," Open Access Library Journal, vol. 7, pp. 1-13, 2020.Available at: https://doi.org/10.4236/oalib.1 106161.

[26] D. Ghernaout and N. Elboughdiri, "Vacuum-UV radiation at $185 \mathrm{~nm}$ for disinfecting water," Chemical Science \& Engineering Research, vol. 2, pp. 12-17, 2020.Available at: https://doi.org/10.36686/ariviyal.cser.2020.02.04.015.

[27] D. Ghernaout, "Advanced oxidation phenomena in electrocoagulation process: A myth or a reality?," Desalination and Water Treatment, vol. 51, pp. 7536-7554, 2013.Available at: https://doi.org/10.1080/19443994.2013.792520.

[28] D. Ghernaout, "Microorganisms' electrochemical disinfection phenomena," EC Microbiology, vol. 9, pp. 160-169, 2017.

[29] D. Ghernaout, Y. Alshammari, A. Alghamdi, M. Aichouni, M. Touahmia, and N. Ait Messaoudene, "Water reuse: Extenuating membrane fouling in membrane processes," International Journal of Environmental Chemistry, vol. 2, pp. 1$12,2018$.

[30] Y. Kellali and D. Ghernaout, "Physicochemical and algal study of three dams (Algeria) and removal of microalgae by enhanced coagulation," Applied Engineering, vol. 3, pp. 56-64, 2019.

[31] D. Ghernaout, "Brine recycling: Towards membrane processes as the best available technology," Applied Engineering, vol. 3, pp. 71-84, 2019.

[32] P. T. Anastas, "Circularity. What's the problem?," ACS Sustainable Chemistry Eீ Engineering, vol. 8, pp. 13111-13111, 2020.Available at: https://doi.org/10.1021/acssuschemeng.Oc05714. 
[33] D. Wang, N. B. Saleh, W. Sun, C. M. Park, C. Shen, N. Aich, W. J. Peijnenburg, W. Zhang, Y. Jin, and C. Su, "Nextgeneration multifunctional carbon-metal nanohybrids for energy and environmental applications," Environmental Science ङ Technology, vol. 53, pp. 7265-7287, 2019.Available at: https://doi.org/10.1021/acs.est.9b01453.

[34] C. Halliday and T. A. Hatton, "Net-negative emissions through molten sorbents and bioenergy with carbon capture and storage," Industrial \& Engineering Chemistry Research, vol. 59, pp. 22582-22596, 2020.Available at: https://doi.org/10.1021/acs.iecr.0c04512.

[35] Y. Jiang, X.-C. Shi, P. Tan, S.-C. Qi, C. Gu, T. Yang, S.-S. Peng, X.-Q. Liu, and L.-B. Sun, "Controllable CO2 capture in metal-organic frameworks: Making targeted active sites respond to light," Industrial \& Engineering Chemistry Research, vol. 59, pp. 2 1894-2 1900, 2020.Available at: https://doi.org/10.102 1/acs.iecr.0c04126.

[36] M. R. Madsen, J. B. Jakobsen, M. H. Rønne, H. Liang, H. C. D. Hammershøj, P. Nørby, S. U. Pedersen, T. Skrydstrup, and K. Daasbjerg, "Evaluation of the electrocatalytic reduction of carbon dioxide using Rhenium and Ruthenium bipyridine catalysts bearing pendant amines in the secondary coordination sphere," Organometallics, vol. 39, pp. 14801490, 2020.Available at: https://doi.org/10.1021/acs.organomet.9bo0815.

[37] Y. Cui, B. He, X. Liu, and J. Sun, "Ionic liquids-promoted electrocatalytic reduction of carbon dioxide," Industrial $\S^{\circ}$ Engineering Chemistry Research, vol. 59, pp. 20235-20252, 2020.Available at: https://doi.org/10.1021/acs.iecr.0c04037.

[38] L. Iffland, A. Khedkar, A. Petuker, M. Lieb, F. Wittkamp, M. van Gastel, M. Roemelt, and U.-P. Apfel, "Solventcontrolled $\mathrm{CO} 2$ reduction by a triphos-iron hydride complex," Organometallics, vol. 38, pp. 289-299, 2019.Available at: https://doi.org/10.1021/acs.organomet.8bo0711.

[39] S.-H. Jun, J. Yang, H. Jeon, H. S. Kim, S. P. Pack, E. Jin, and J. Kim, "Stabilized and immobilized carbonic anhydrase on electrospun nanofibers for enzymatic $\mathrm{CO} 2$ conversion and utilization in expedited microalgal growth," Environmental Science E̊ Technology, vol. 54, pp. 1223-1231, 2020.Available at: https://doi.org/10.1021/acs.est.9b05284.

[40] C. Yang, M. D. Karkas, G. Magallanes, K. Chan, and C. R. Stephenson, "Organocatalytic approach to photochemical lignin fragmentation," Organic Letters, vol. 22, pp. 8082-8085, 2020.Available at: https://doi.org/10.1021/acs.orglett.0c03029.

[41] J. Xu, A. He, B. Wu, L. Hu, X. Liu, Z. Wu, J. Xia, J. Xu, and S. Zhou, "Redox-switchable biocatalyst for controllable oxidation or reduction of 5-hydroxymethylfurfural into high-value derivatives," ACS Omega, vol. 5, pp. 19625-19632, 2020.Available at: https://doi.org/10.1021/acsomega.0c02178.

[42] J. C. Del Río, J. Rencoret, A. Gutiérrez, T. Elder, H. Kim, and J. Ralph, "Lignin monomers from beyond the canonical monolignol biosynthetic pathway: Another brick in the wall," ACS Sustainable Chemistry \& Engineering, vol. 8, pp. 49975012, 2020.Available at: https://doi.org/10.1021/acssuschemeng.Oc01109.

[43] Y. Nakagawa, T. Kasumi, J. Ogihara, M. Tamura, T. Arai, and K. Tomishige, "Erythritol: Another C4 platform chemical in biomass refinery," ACS Omega, vol. 5, pp. 2520-2530, 2020.Available at: https://doi.org/10.1021/acsomega.9b04046.

[44] H. Dong, L. Zheng, P. Yu, Q. Jiang, Y. Wu, C. Huang, and B. Yin, "Characterization and application of lignincarbohydrate complexes from lignocellulosic materials as antioxidants for scavenging in vitro and in vivo reactive oxygen species," ACS Sustainable Chemistry छ Engineering, vol. 8, pp. 256-266, 2019.Available at: https://doi.org/10.1021/acssuschemeng.9b05290.

[45] J. Jeong, W. S. Kim, M. W. Lee, and M. Goh, "Liquefaction of lignin using chemical decomposition and its application to polyurethane foam," ACS Omega, vol. 6, pp. 10745-10751, 2021.Available at: https://doi.org/10.1021/acsomega.1c00285.

[46] R. S. Varma, "Biomass-derived renewable carbonaceous materials for sustainable chemical and environmental applications," ACS Sustainable Chemistry \& Engineering, vol. 7, pp. 6458-6470, 2019.Available at: https://doi.org/10.1021/acssuschemeng.8b06550. 
[47] W. Liu, H. Du, M. Zhang, K. Liu, H. Liu, H. Xie, X. Zhang, and C. Si, "Bacterial cellulose-based composite scaffolds for biomedical applications: A review," ACS Sustainable Chemistry \& Engineering, vol. 8, pp. 7536-7562, 2020.Available at: https://doi.org/10.1021/acssuschemeng.0c00125.

[48] X. Zhao, K. Cornish, and Y. Vodovotz, "Narrowing the gap for bioplastic use in food packaging: An update," Environmental Science \& Technology, vol. 54, pp. 4712-4732, 2020.Available at: https://doi.org/10.1021/acs.est.9b03755.

[49] D. Ghernaout and N. Elboughdiri, "Plastic waste pollution worsen by the COVID-19 pandemic: Substitutional technologies transforming plastic waste to value added products," Open Access Library Journal, vol. 8, pp. 1-12, 2021.Available at: https://doi.org/10.4236/oalib.1107622.

[50] D. Ghernaout, A. Alghamdi, M. Aichouni, and M. Touahmia, "The lethal water tri-therapy: Chlorine, alum, and polyelectrolyte," World Journal of Applied Chemistry, vol. 3, pp. 65-71, 2018.Available at: https://doi.org/10.11648/j.wjac.20180302.14

[51] D. Ghernaout and N. Elboughdiri, "Is not it time to stop using chlorine for treating water?," Open Access Library Journal, vol. 7, pp. 1-11, 2020.Available at: https://doi.org/10.4236/oalib.1 106007.

[52] D. Ghernaout, M. W. Naceur, and A. Aouabed, "On the dependence of chlorine by-products generated species formation of the electrode material and applied charge during electrochemical water treatment," Desalination, vol. 270, pp. 9-22, 2011.Available at: https://doi.org/10.1016/j.desal.2011.01.010.

[53] D. Ghernaout and N. Elboughdiri, "Antibiotics resistance in water mediums: Background, facts, and trends," Applied Engineering, vol. 4, pp. 1-6, 2020.

[54] D. Ghernaout and R. O. Ibn-Elkhattab, "Removing antibiotic-resistant bacteria (ARB) carrying genes (ARGs): Challenges and future trends," Open Access Library Journal, vol. 7, pp. 1-16, 2020.Available at: https://doi.org/10.4236/oalib.1 106003.

[55] D. Ghernaout and N. Elboughdiri, "Should we forbid the consumption of antibiotics to stop the spread of resistances in nature?," Open Access Library Journal, vol. 7, pp. 1-12, 2020.Available at: https://doi.org/10.4236/oalib.1 106138.

[56] D. Ghernaout and N. Elboughdiri, "Environmental engineering for stopping viruses pandemics," Open Access Library Journal, vol. 7, pp. 1-17, 2020.Available at: https://doi.org/10.4236/oalib.1 106299.

[57] D. Ghernaout, "Desalination engineering: Environmental impacts of the brine disposal and their control," Open Access Library Journal, vol. 7, p. e6777, 2020.Available at: https://doi.org/10.4236/oalib.1 106777.

[58] D. Ghernaout, N. Elboughdiri, and S. Ghareba, "Fenton technology for wastewater treatment: Dares and trends," Open Access Library Journal, vol. 7, pp. 1-26, 2020.Available at: https://doi.org/10.4236/oalib.1106045.

[59] D. P. Debecker, K. K. Hii, A. Moores, L. M. Rossi, B. Sels, D. T. Allen, and B. Subramaniam, "Shaping effective practices for incorporating sustainability assessment in manuscripts submitted to ACS sustainable Chemistry \& engineering: Catalysis and catalytic processes," ACS Sustainable Chemistry Eீ Engineering, vol. 9, pp. 4936-4940, 2021.Available at: https://doi.org/10.1021/acssuschemeng.1 1c02070.

[60] D. M. Heard and A. J. Lennox, "Dichloromeldrum's acid (DiCMA): A practical and green amine dichloroacetylation reagent," Organic Letters, vol. 23, pp. 3368-3372, 2021 .Available at: https://doi.org/10.102 1/acs.orglett.1 c00850.

[61] M. Majdecki, A. Tyszka-Gumkowska, and J. Jurczak, "Highly enantioselective epoxidation of $\alpha, \beta$-unsaturated ketones using amide-based cinchona alkaloids as hybrid phase-transfer catalysts," Organic Letters, vol. 22, pp. 8687-8691, 2020.Available at: https://doi.org/10.1021/acs.orglett.0c03272.

[62] A. Nitti, P. Osw, G. Calcagno, C. Botta, S. I. Etkind, G. Bianchi, and D. Pasini, "One-pot regiodirected annulations for the rapid synthesis of $\pi$-extended oligomers," Organic Letters, vol. 22, pp. 3263-3267, 2020.Available at: https://doi.org/10.1021/acs.orglett.0c01043.

[63] R. J. Key, J. M. M. Tengco, M. D. Smith, and A. K. Vannucci, "A molecular/heterogeneous nickel catalyst for SuzukiMiyaura coupling," Organometallics, vol. 38, pp. 2007-2014, 2019.Available at: https://doi.org/10.1021/acs.organomet.9booo82. 
[64] Y. Tian, X. Guo, M. Li, C. Li, X. Hu, L. Jin, N. Sun, B. Hu, and Z. Shen, "SBA-15 supported 1-methyl-2-azaadamanane n-oxyl (1-Me-AZADO) as recyclable catalyst for oxidation of alcohol," Organic Letters, vol. 23, 2021.Available at: https://doi.org/10.1021/acs.orglett.1c01058.

[65] G. Wang, F. Li, L. Li, J. Zhao, X. Ruan, W. Ding, J. Cai, A. Lu, and Y. Pei, "In situ synthesis of Ag-Fe3O4 nanoparticles immobilized on pure cellulose microspheres as recyclable and biodegradable catalysts," ACS Omega, vol. 5, pp. 8839-8846, 2020.Available at: https://doi.org/10.1021/acsomega.0c00437.

[66] B. I. Andrews, F. D. Antia, S. B. Brueggemeier, L. J. Diorazio, S. G. Koenig, M. E. Kopach, H. Lee, M. Olbrich, and A. L. Watson, "Sustainability challenges and opportunities in oligonucleotide manufacturing," The Journal of Organic Chemistry, vol. 86, pp. 49-61, 2020.Available at: https://doi.org/10.1021/acs.joc.0c02291.

[67] A. Isidro-Llobet, M. N. Kenworthy, S. Mukherjee, M. E. Kopach, K. Wegner, F. Gallou, A. G. Smith, and F. Roschangar, "Sustainability challenges in peptide synthesis and purification: From R\&D to production," The Journal of Organic Chemistry, vol. 84, pp. 4615-4628, 2019.Available at: https://doi.org/10.1021/acs.joc.8b03001.

[68] K. Rossen, "Greening organic Chemistry with process Chemistry," The Journal of Organic Chemistry, vol. 84, pp. 45804582, 2019.Available at: https://doi.org/10.1021/acs.joc.9bo0344.

[69] J. D. Hayler, D. K. Leahy, and E. M. Simmons, "A pharmaceutical industry perspective on sustainable metal catalysis," Organometallics, vol. 38, pp. 36-46, 2018.Available at: https://doi.org/10.1021/acs.organomet.8bo0566.

[70] D. Kim, C. Chen, B. Q. Mercado, D. J. Weix, and P. L. Holland, "Mechanistic study of alkene hydrosilylation catalyzed by a $\beta$-dialdiminate cobalt (I) complex," Organometallics, vol. 39, pp. 2415-2424, 2020.Available at: https://doi.org/10.1021/acs.organomet.0c00241.

[71] P. V. S. Nylund, N. C. Ségaud, and M. Albrecht, "Highly modular piano-stool n-heterocyclic carbene iron complexes: Impact of ligand variation on hydrosilylation activity," Organometallics, vol. 40, pp. 1538-1550, 2021.Available at: https://doi.org/10.1021/acs.organomet.1c00200.

[72] R. Van Putten, G. A. Filonenko, A. M. Krieger, M. Lutz, and E. A. Pidko, "Manganese-mediated C-C bond formation: Alkoxycarbonylation of organoboranes," Organometallics, vol. 40, pp. 674-681, 2021.Available at: https://doi.org/10.1021/acs.organomet.0c00781.

[73] D. Ghernaout, "Demobilizing antibiotic-resistant bacteria and antibiotic resistance genes by electrochemical technology: New insights," Open Access Library Journal, vol. 7, pp. 1-18, 2020.Available at: https://doi.org/10.4236/oalib.1106685.

[74] D. Ghernaout and N. Elboughdiri, "Disinfecting water: Plasma discharge for removing coronaviruses," Open Access Library Journal, vol. 7, pp. 1-29, 2020.Available at: https://doi.org/10.4236/oalib.1 106314.

[75] D. Ghernaout and N. Elboughdiri, "Solar treatment in the core of the new disinfection technologies," Chemical Science E Engineering Research, vol. 2, pp. 6-1 1, 2020.Available at: https://doi.org/10.36686/ariviyal.cser.2020.02.04.014.

[76] D. Ghernaout and N. Elboughdiri, "Disinfection by-products regulation: Zero ng/L target," Open Access Library Journal, vol. 7, p. e6382, 2020.Available at: https://doi.org/10.4236/oalib.1 106382.

[77] D. Ghernaout and N. Elboughdiri, "Dealing with cyanobacteria and cyanotoxins: Engineering viewpoints," Open Access Library Journal, vol. 7, p. e6363, 2020.Available at: https://doi.org/10.4236/oalib.1 106363.

[78] D. Ghernaout and N. Elboughdiri, "On the disinfection chain as a new technique for economic and chemical free disinfection of public places from viruses," Saudi Journal of Engineering and Technology, vol. 6, pp. 130-138, 2021.

[79] A. Saiba, S. Kourdali, B. Ghernaout, and D. Ghernaout, "In Desalination, from 1987 to 2009, the birth of a new seawater pretreatment process: Electrocoagulation-an overview," Desalination and Water Treatment, vol. 16, pp. 201217, 2010.Available at: https://doi.org/10.5004/dwt.2010.1094.

[80] A. Boucherit, S. Moulay, D. Ghernaout, A. I. Al-Ghonamy, B. Ghernaout, M. W. Naceur, N. Ait Messaoudene, M. Aichouni, A. A. Mahjoubi, and N. A. Elboughdiri, "New trends in disinfection by-products formation upon water treatment," Journal of Research \& Developments in Chemistry, vol. 2015, pp. 1-27, 2015. 
[81] Q. Chen, X. Wang, H. Tan, W. Shi, X. Zhang, S. Wei, J. P. Giesy, and H. Yu, "Molecular initiating events of Bisphenols on androgen receptor-mediated pathways provide guidelines for in silico screening and design of substitute compounds," Environmental Science \& Technology Letters, vol. 6, pp. 205-210, 2019.Available at: https://doi.org/10.1021/acs.estlett.9boo073.

[82] C. F. Kwiatkowski, D. Q. Andrews, L. S. Birnbaum, T. A. Bruton, J. C. DeWitt, D. R. Knappe, M. V. Maffini, M. F. Miller, K. E. Pelch, and A. Reade, "Scientific basis for managing PFAS as a chemical class," Environmental Science $\mathcal{E}^{\circ}$ Technology Letters, vol. 7, pp. 532-543, 2020.Available at: https://doi.org/10.1021/acs.estlett.0c00255.

[83] A. Blum, M. Behl, L. S. Birnbaum, M. L. Diamond, A. Phillips, V. Singla, N. S. Sipes, H. M. Stapleton, and M. Venier, "Organophosphate ester flame retardants: Are they a regrettable substitution for polybrominated diphenyl ethers?," Environmental Science \& Technology Letters, vol. 6, pp. 638-649, 2019.Available at: https://doi.org/10.1021/acs.estlett.9b00582.

[84] I. E. Napper and R. C. Thompson, "Environmental deterioration of biodegradable, oxo-biodegradable, compostable, and conventional plastic carrier bags in the sea, soil, and open-air over a 3-year period," Environmental science $\mathcal{E}^{\circ}$ technology, vol. 53, pp. 4775-4783, 2019.Available at: https://doi.org/10.1021/acs.est.8b06984.

[85] J. Grbic, B. Nguyen, E. Guo, J. B. You, D. Sinton, and C. M. Rochman, "Magnetic extraction of microplastics from environmental samples," Environmental Science छ Technology Letters, vol. 6, pp. 68-72, 2019.Available at: https://doi.org/10.1021/acs.estlett.8b00671.

[86] D. Ghernaout, "The hydrophilic/hydrophobic ratio vs. dissolved organics removal by coagulation-A review," Journal of King Saud University-Science, vol. 26, pp. 169-180, 2014.Available at: https://doi.org/10.1016/j.jksus.2013.09.005.

[87] D. Ghernaout, "Increasing trends towards drinking water reclamation from treated wastewater," World Journal of Applied Chemistry, vol. 3, pp. 1-9, 2018.Available at: https://doi.org/10.11648/j.wjac.20180301.11.

[88] D. Ghernaout, "Aeration process for removing radon from drinking water - A review," Applied Engineering, vol. 3, pp. $32-45,2019$.

[89] U. Ghimire, G. Sarpong, and V. G. Gude, "Transitioning wastewater treatment plants toward circular economy and energy sustainability," ACS Omega, vol. 6, pp. 11794-11803, 2021.Available at: https://doi.org/10.1021/acsomega.0c05827.

[90] D. Ghernaout, N. Elboughdiri, and S. Ghareba, "Drinking water reuse: One-step closer to overpassing the yuck factor," Open Access Library Journal, vol. 6, p. e5895, 2019.Available at: https://doi.org/ 10.4236/oalib. 1105895.

[91] D. Ghernaout and N. Elboughdiri, "Upgrading wastewater treatment plant to obtain drinking water," Open Access Library Journal, vol. 6, pp. 1-14, 2019.Available at: https://doi.org/10.4236/oalib.1 105959.

[92] D. Ghernaout and N. Elboughdiri, "Disinfection by-products: Presence and elimination in drinking water," Open Access Library Journal, vol. 7, pp. 1-27, 2020.Available at: https://doi.org/10.4236/oalib.1 106140.

[93] C. G. Eggensperger, M. Giagnorio, M. C. Holland, K. M. Dobosz, J. D. Schiffman, A. Tiraferri, and K. R. Zodrow, "Sustainable living filtration membranes," Environmental Science \& Technology Letters, vol. 7, pp. $213-218,2020$.

[94] M. J. Bentel, Z. Liu, Y. Yu, J. Gao, Y. Men, and J. Liu, "Enhanced degradation of perfluorocarboxylic acids (PFCAs) by UV/sulfite treatment: Reaction mechanisms and system efficiencies at pH 12," Environmental Science \& Technology Letters, vol. 7, pp. 351-357, 2020.Available at: https://doi.org/10.1021/acs.estlett.0c00236.

[95] D. Ghernaout, "New configurations and techniques for controlling membrane bioreactor (MBR) fouling," Open Access Library Journal, vol. 7, pp. 1-18, 2020.Available at: https://doi.org/10.4236/oalib.1 106579.

[96] M. I. Khan, A. Shanableh, N. Elboughdiri, K. Kriaa, D. Ghernaout, S. Ghareba, M. Khraisheh, and M. H. Lashari, "Higher acid recovery efficiency of novel functionalized inorganic/organic composite anion exchange membranes from acidic wastewater," Membranes, vol. 11, p. 133, 2021 .Available at: https://doi.org/10.3390/membranes 11020133.

[97] N. A. Messaoudene, M. W. Naceur, D. Ghernaout, A. Alghamdi, and M. Aichouni, "On the validation perspectives of the proposed novel dimensionless fouling index," International Journal of Advances in Applied Sciences, vol. 5, pp. 116-122, 2018. 
[98] D. Ghernaout and A. El-Wakil, "Requiring reverse osmosis membranes modifications - An overview," American Journal of Chemical Engineering, vol. 5, pp. 81-88, 2017.Available at: https://doi.org/10.11648/j.ajche.20170504.15.

[99] D. Ghernaout, A. El-Wakil, A. Alghamdi, N. Elboughdiri, and A. Mahjoubi, "Membrane post-synthesis modifications and how it came about," International Journal of Advanced and Applied Sciences, vol. 5, pp. 60-64, 2018.Available at: https://doi.org/10.21833/ijaas.2018.02.010.

[100] H. Luo, K. Chang, K. Bahati, and G. M. Geise, "Engineering selective desalination membranes via molecular control of polymer functional groups," Environmental Science E Technology Letters, vol. 6, pp. 462-466, 2019.Available at: https://doi.org/10.1021/acs.estlett.9b00351.

[101] S. Yuan, Y. Li, Y. Xia, Y. Kang, J. Yang, M. H. Uddin, H. Liu, C. Selomulya, and X. Zhang, "Minimizing non-selective nanowrinkles of reduced graphene oxide laminar membranes for enhanced $\mathrm{NaCl}$ rejection," Environmental Science $\mathbb{E}^{\circ}$ Technology Letters, vol. 7, pp. 273-279, 2020.Available at: https://doi.org/10.102 1/acs.estlett.0c00143.

[102] D. Pan, S. Xiao, X. Chen, R. Li, Y. Cao, D. Zhang, S. Pu, Z. Li, G. Li, and H. Li, "Efficient photocatalytic fuel cell via simultaneous visible-photoelectrocatalytic degradation and electricity generation on a porous coral-like WO3/W photoelectrode," Environmental Science \& Technology, vol. 53, pp. 3697-3706, 2019.Available at: https://doi.org/10.1021/acs.est.8b05685.

[103] P. Shao, S. Yu, X. Duan, L. Yang, H. Shi, L. Ding, J. Tian, L. Yang, X. Luo, and S. Wang, "Potential difference driving electron transfer via defective carbon nanotubes toward selective oxidation of organic micropollutants," Environmental Science Eீ Technology, vol. 54, pp. 8464-8472, 2020.Available at: https://doi.org/10.102 1/acs.est.0c02645.

[104] A. Chamas, H. Moon, J. Zheng, Y. Qiu, T. Tabassum, J. H. Jang, M. Abu-Omar, S. L. Scott, and S. Suh, "Degradation rates of plastics in the environment," ACS Sustainable Chemistry \& Engineering, vol. 8, pp. 3494-351 1, 2020.

[105] K. Parker, G. K. Weragoda, A. J. Canty, V. Ryzhov, and R. A. O’Hair, "Modeling metal-catalyzed polyethylene depolymerization: $[(\mathrm{Phen}) \mathrm{Pd}(\mathrm{X})]+(\mathrm{X}=\mathrm{H}$ and $\mathrm{CH} 3)$ catalyze the decomposition of hexane into a mixture of alkenes via a complex reaction network," Organometallics, vol. 40, pp. 857-868, 2021.Available at: https://doi.org/10.1021/acs.organomet.0c00782.

[106] K. Liu, Q. Tan, L. Liu, and J. Li, "Acid-free and selective extraction of lithium from spent lithium iron phosphate batteries via a mechanochemically induced isomorphic substitution," Environmental Science \& Technology, vol. 53, pp. 9781-9788, 2019.Available at: https://doi.org/10.1021/acs.est.9b01919.

[107] B. Wu, J. Wan, Y. Zhang, B. Pan, and I. M. Lo, "Selective phosphate removal from water and wastewater using sorption: Process fundamentals and removal mechanisms," Environmental Science \& Technology, vol. 54, pp. 50-66, 2019.Available at: https://doi.org/10.1021/acs.est.9b05569.

[108] S. P. Munasinghe-Arachchige and N. Nirmalakhandan, "Nitrogen-fertilizer recovery from the centrate of anaerobically digested sludge," Environmental Science \& Technology Letters, vol. 7, pp. 450-459, 2020.Available at: https://doi.org/10.1021/acs.estlett.0c00355.

[109] Y. Luo and M. Ierapetritou, "Comparison between different hybrid life cycle assessment methodologies: A review and case study of biomass-based p-xylene production," Industrial \& Engineering Chemistry Research, vol. 59, pp. 2231322329, 2020.Available at: https://doi.org/10.1021/acs.iecr.0c04709.

[110] F. Wu, Z. Zhou, and A. L. Hicks, "Life cycle impact of titanium dioxide nanoparticle synthesis through physical, chemical, and biological routes," Environmental Science \& Technology, vol. 53, pp. 4078-4087, 2019.Available at: https://doi.org/10.1021/acs.est.8b06800.

[111] Y. Shen, F. Zhao, X. Qiu, H. Zhang, D. Yao, S. Wang, Z. Zhu, J. Yang, P. Cui, and Y. Wang, "Economic, thermodynamic, and environmental analysis and comparison of the synthesis process of butyl acetate," Industrial \&० Engineering Chemistry Research, vol. 59, pp. 2 1869-2 1881, 2020.Available at: https://doi.org/10.102 1/acs.iecr.0c04233.

[112] S. Parkinson and J. Hunt, "Economic potential for rainfed agrivoltaics in groundwater-stressed regions," Environmental Science \& Technology Letters, vol. 7, pp. 525-531, 2020.Available at: https://doi.org/10.102 1/acs.estlett.0c00349. 
[113] D. Ghernaout, M. Aichouni, and A. Alghamdi, "Applying big data in water treatment industry: A new era of advance," International Journal of Advanced and Applied Sciences, vol. 5, pp. 89-97, 2018.Available at: https://doi.org/10.21833/ijaas.2018.03.013.

[114] D. Ghernaout, M. Aichouni, and N. A. Messaoudene, "Big data: Myths, realities and perspectives-A remote look," American Journal of Information Science and Technology, vol. 2, pp. 1-8, 2018.Available at: https://doi.org/10.11648/j.ajist.20180201.11.

[115] D. Ghernaout, M. Aichouni, and A. Alghamdi, "Overlapping ISO/IEC 17025:2017 into big data: A review and perspectives," International Journal of Science Quality Anal, vol. 4, pp. 83-92, 2018.

[116] D. Reay, C. Ramshaw, and A. Harvey, Process intensification: Engineering for efficiency, sustainability and flexibility, 2 nd ed. Amsterdam: Elsevier, 2013.

[117] K. Boodhoo and A. Harvey, Process intensification: An overview of principles and practice (Ch. 1), Process intensification for green chemistry: Engineering solutions for sustainable chemical processing, K. Boodhoo, A. Harvey (Eds.), 1st ed. New York: John Wiley \& Sons, Ltd, 2013.

[118] D. Ghernaout and N. Elboughdiri, "Strategies for reducing disinfection by-products formation during electrocoagulation," Open Access Library Journal, vol. 7, pp. 1-9, 2020.Available at: https://doi.org/10.4236/oalib.1 106076.

[119] D. Ghernaout and N. Elboughdiri, "Controlling disinfection by-products formation in rainwater: Technologies and trends," Open Access Library Journal, vol. 7, p. e6162, 2020.Available at: https://doi.org/10.4236/oalib.1106162.

[120] D. Ghernaout, N. Elboughdiri, A. Alghamdi, and B. Ghernaout, "Trends in decreasing disinfection by-products formation during electrochemical technologies," Open Access Library Journal, vol. 7, pp. 1-17, 2020.Available at: https://doi.org/10.4236/oalib.1 106337.

[121] D. Ghernaout and N. Elboughdiri, "Foresight look on the disinfection by-products formation," Open Access Library Journal, vol. 7, p. e6349, 2020.Available at: https://doi.org/10.4236/oalib.1106349.

[122] D. Ghernaout and N. Elboughdiri, "Disinfection by-products (DBPs) control strategies in electrodisinfection," Open Access Library Journal, vol. 7, pp. 1-14, 2020.Available at: https://doi.org/10.4236/oalib.1 106396.

[123] D. Ghernaout and M. Naceur, "Ferrate (VI): In situ generation and water treatment-A review," Desalination and Water Treatment, vol. 30, pp. 319-332, 2011 .Available at: https://doi.org/10.5004/dwt.2011.2217.

[124] D. Ghernaout, M. Naceur, and B. Ghernaout, "A review of electrocoagulation as a promising coagulation process for improved organic and inorganic matters removal by electrophoresis and electroflotation," Desalination and Water Treatment, vol. 28, pp. 287-320, 2011.Available at: https://doi.org/10.5004/dwt.2011.1493.

[125] D. Ghernaout and B. Ghernaout, "Sweep flocculation as a second form of charge neutralisation-a review," Desalination and Water Treatment, vol. 44, pp. 15-28, 2012.Available at: https://doi.org/10.1080/19443994.2012.691699.

[126] D. Ghernaout, A. I. Al-Ghonamy, M. W. Naceur, N. A. Messaoudene, and M. Aichouni, "Influence of operating parameters on electrocoagulation of CI disperse yellow 3," Journal of Electrochemical Science and Engineering, vol. 4, pp. 271-283, 2014.Available at: https://doi.org/10.5599/jese.2014.0065.

[127] D. Ghernaout, A. I. Al-Ghonamy, S. Irki, A. Grini, M. W. Naceur, N. Ait Messaoudene, and M. Aichouni, "Decolourization of bromophenol blue by electrocoagulation process," Trends in Chemical Engineering, vol. 15, pp. 29$39,2014$.

[128] D. Ghernaout, C. Benblidia, and F. Khemici, "Microalgae removal from Ghrib Dam (Ain Defla, Algeria) water by electroflotation using stainless steel electrodes," Desalination and Water Treatment, vol. 54, pp. 3328-3337, 2015.Available at: https://doi.org/10.1080/19443994.2014.907749.

[129] D. Ghernaout, A. I. Al-Ghonamy, A. Boucherit, B. Ghernaout, M. W. Naceur, N. Ait Messaoudene, M. Aichouni, A. A. Mahjoubi, and N. A. Elboughdiri, "Brownian motion and coagulation process," American Journal of Environmental Protection, vol. 4, pp. 1-15, 2015.Available at: https://doi.org/10.11648/j.ajeps.s.2015040501.11. 
[130] D. Ghernaout, A. I. Al-Ghonamy, M. W. Naceur, A. Boucherit, N. A. Messaoudene, M. Aichouni, A. A. Mahjoubi, and N. A. Elboughdiri, "Controlling coagulation process: From Zeta potential to streaming potential," American Journal of Environmental Protection, vol. 4, pp. 16-27, 2015.Available at: https://doi.org/10.11648/j.ajeps.s.2015040501.12.

[131] D. Ghernaout, A. I. Al-Ghonamy, N. Ait Messaoudene, M. Aichouni, M. W. Naceur, F. Z. Benchelighem, and A. Boucherit, "Electrocoagulation of direct brown 2 (DB) and BF cibacete blue (CB) using aluminum electrodes," Separation Science and Technology, vol. 50, pp. 1413-1420, 2015.Available at: https://doi.org/10.1080/01496395.2014.982763.

[132] M. Rossini, G. Garrido, and M. Galluzzo, "Optimization of the coagulation-flocculation treatment: Influence of rapid mix parameters," Water Research, vol. 33, pp. 1817-1826, 1999.Available at: https://doi.org/10.1016/So0431354(98)00367-4.

[133] D. Ghernaout, "Elimination of humic substances and germs indicative of bacteriological contamination by electrocoagulation assisted by magnetic treatment of water," Ph.D. Thesis, University of Blida, Algeria, 2008.

[134] D. Ghernaout, A. Simoussa, A. Alghamdi, B. Ghernaout, N. Elboughdiri, A. Mahjoubi, M. Aichouni, and A. E.-A. ElWakil, "Combining lime softening with alum coagulation for hard Ghrib dam water conventional treatment," International Journal of Advanced and Applied Sciences, vol. 5, pp. 61-70, 2018.Available at: https://doi.org/10.21833/ijaas.2018.05.008.

[135] D. Ghernaout, C. Laribi, A. Alghamdi, B. Ghernaout, N. Ait Messaoudene, and M. Aichouni, "Decolorization of BF Cibacete Blue (CB) and Red Solophenyle 3BL (RS) using aluminum sulfate and ferric chloride," World Journal of Applied Chemistry, vol. 3, pp. 32-40, 2018.Available at: https://doi.org/10.11648/j.wjac.20180302.11.

[136] S. Djezzar, D. Ghernaout, H. Cherifi, A. Alghamdi, B. Ghernaout, and M. Aichouni, "Conventional, enhanced, and alkaline coagulation for hard Ghrib Dam (Algeria) water," World Journal of Applied Chemistry, vol. 3, pp. 41-55, 2018.Available at: https://doi.org/10.11648/j.wjac.20180302.12.

[137] S. Irki, D. Ghernaout, M. W. Naceur, A. Alghamdi, and M. Aichouni, "Decolorizing methyl orange by Feelectrocoagulation process - A mechanistic insight," International Journal of Environmental Chemistry, vol. 2, pp. 18-28, 2018.Available at: https://doi.org/10.11648/j.ijec.20180201.14.

[138] Y. Alshammari, D. Ghernaout, M. Aichouni, and M. Touahmia, "Improving operational procedures in Riyadh's (Saudi Arabia) water treatment plants using quality tools," Applied Engineering, vol. 2, pp. 60-71, 2018.

[139] D. Ghernaout, M. Touahmia, and M. Aichouni, "Disinfecting water: Electrocoagulation as an efficient process," Applied Engineering, vol. 3, pp. 1-12, 2019.

[140] D. Ghernaout, M. Aichouni, and M. Touahmia, "Mechanistic insight into disinfection by electrocoagulation-A review," Desalination and Water Treatment, vol. 141, pp. 68-81, 2019.Available at: https://doi.org/10.5004/dwt.2019.23457.

[141] D. Ghernaout, A. Alghamdi, and B. Ghernaout, "Electrocoagulation process: A mechanistic review at the dawn of its modeling," Journal of Environmental Science and Allied Research, vol. 2, pp. 22-38, 2019.Available at: https://doi.org/10.29199/2637-7063/esar-201019.

[142] D. Ghernaout, A. Boudjemline, and N. Elboughdiri, "Electrochemical engineering in the core of the dye-sensitized solar cells (DSSCs)," Open Access Library Journal, vol. 7, pp. 1-12, 2020.Available at: https://doi.org/10.4236/oalib.1 106178.

[143] D. Ghernaout, N. Elboughdiri, S. Ghareba, and A. Salih, "Electrochemical advanced oxidation processes (EAOPs) for disinfecting water - fresh perspectives," Open Access Library Journal, vol. 7, p. e6257, 2020.Available at: https://doi.org/10.4236/oalib.1 106257.

[144] D. Ghernaout and N. Elboughdiri, "On the other side of viruses in the background of water disinfection," Open Access Library Journal, vol. 7, pp. 1-29, 2020.Available at: https://doi.org/10.4236/oalib.1 106374. 
[145] N. M. Nikačević, A. E. Huesman, P. M. Van den Hof, and A. I. Stankiewicz, "Opportunities and challenges for process control in process intensification," Chemical Engineering and Processing: Process Intensification, vol. 52, pp. 1-15, 2012.Available at: https://doi.org/10.1016/j.cep.2011.11.006.

[146] D. Ghiasy, K. Boodhoo, and M. Tham, "Control of intensified equipment: A simulation study for $\mathrm{pH}$ control in a spinning disc reactor," Chemical Engineering and Processing: Process Intensification, vol. 55, pp. 1-7, 2012.Available at: https://doi.org/10.1016/j.cep.2012.02.009.

[147] Z. Wu, S. Tagliapietra, A. Giraudo, K. Martina, and G. Cravotto, "Harnessing cavitational effects for green process intensification," Ultrasonics Sonochemistry, vol. 52, pp. 530-546, 2019.Available at: https://doi.org/10.1016/j.ultsonch.2018.12.032.

Views and opinions expressed in this article are the views and opinions of the author(s), International Journal of Chemistry and Materials Research shall not be responsible or answerable for any loss, damage or liability etc. caused in relation to/arising out of the use of the content. 